\title{
Intra-articular CD1c-expressing myeloid dendritic cells from rheumatoid arthritis patients express a unique set of T cell-attracting chemokines and spontaneously induce Th1, Th17 and Th2 cell activity
}

Frederique M Moret ${ }^{1 *}$, Cornelis E Hack², Kim MG van der Wurff-Jacobs ${ }^{1}$, Wilco de Jager ${ }^{2}$, Timothy RDJ Radstake ${ }^{1,2}$, Floris PJG Lafeber ${ }^{1}$ and Joel AG van Roon ${ }^{1,2}$

\begin{abstract}
Introduction: Myeloid dendritic cells (mDCs) are potent T cell-activating antigen-presenting cells that have been suggested to play a crucial role in the regulation of immune responses in many disease states, including rheumatoid arthritis (RA). Despite this, studies that have reported on the capacity of naturally occurring circulating $\mathrm{mDCs}$ to regulate $\mathrm{T}$ cell activation in RA are still lacking. This study aimed to evaluate the phenotypic and functional properties of naturally occurring CD1c (BDCA-1) $)^{+} \mathrm{mDCs}$ from synovial fluid (SF) compared to those from peripheral blood (PB) of RA patients.
\end{abstract}

Methods: $\mathrm{CD} 1 \mathrm{c}^{+} \mathrm{mDC}$ numbers and expression of costimulatory molecules were assessed by fluorescence-activated cell sorting (FACS) analysis in SF and PB from RA patients. Ex vivo secretion of 45 inflammatory mediators by mDCs from SF and PB of RA patients was determined by multiplex immunoassay. The capacity of mDCs from SF to activate autologous $\mathrm{CD}^{+} \mathrm{T}$ cells was measured.

Results: $\mathrm{CD} 1 \mathrm{c}^{+} \mathrm{mDC}$ numbers were significantly increased in SF versus PB of RA patients (mean $4.7 \%$ vs. $0.6 \%$ ). $\mathrm{mDCs}$ from SF showed increased expression of antigen-presenting (human leukocyte antigen (HLA) class II, CD1c) and costimulatory molecules (CD80, CD86 and CD40). Numerous cytokines were equally abundantly produced by mDCs from both PB and SF (including IL-12, IL-23, IL-13, IL-21). SF mDCs secreted higher levels of interferon $\gamma$-inducible protein-10 (IP-10), monokine induced by interferon $y$ (MIG) and, thymus and activation-regulated chemokine (TARC), but lower macrophage-derived chemokine (MDC) levels compared to mDCs from PB. mDCs from SF displayed a strongly increased capacity to induce proliferation of $\mathrm{CD}^{+} \mathrm{T}$ cells associated with a strongly augmented IFNY, IL-17, and IL-4 production.

Conclusions: This study suggests that increased numbers of CD1 $\mathrm{c}^{+} \mathrm{mDCs}$ in SF are involved in the inflammatory cascade intra-articularly by the secretion of specific T cell-attracting chemokines and the activation of self-reactive T cells.

\footnotetext{
* Correspondence: f.m.moret@umcutrecht.nl

${ }^{1}$ Department of Rheumatology \& Clinical Immunology, University Medical

Center Utrecht, PO Box 85500, 3508 GA Utrecht, the Netherlands

Full list of author information is available at the end of the article
} 


\section{Introduction}

Rheumatoid arthritis (RA) is an autoimmune disorder characterised by persistent joint inflammation resulting in progressive destruction of the joint tissues [1]. $\mathrm{CD}^{+}{ }^{+} \mathrm{T}$ cells producing $\mathrm{T}$-helper type (Th)-1 (interferon gamma $(\mathrm{IFN} \gamma)$ ) and Th17 cytokines (interleukin (IL)-17) [2-5], as well as B cells of the adaptive immune system and macrophages and dendritic cells (DCs) of the innate immune system all contribute to joint inflammation and immunopathology of RA.

DCs are the professional antigen-presenting cells involved in the coordination of adaptive immune responses during infections and against tumour cells. DCs instruct T cells to develop a proper immune response by uptake and presentation of antigens and the provision of costimulatory signals and cytokines. In addition, DCs have the ability to instruct $\mathrm{T}$ cells to induce self-tolerance by presenting selfantigens to $\mathrm{T}$ cells and subsequent deletion or inactivation of self-reactive T cells [6]. External agents to DCs such as cytokines, tissue-derived factors, pathogen-derived antigens and organic molecules may alter the balance between tolerogenic and immunogenic activity of DCs and induce autoimmune disease $[7,8]$.

Human blood DCs are divided into several phenotypically and functionally different subpopulations including myeloid dendritic cells (mDCs) [9]. mDCs express CD11c and are subdivided into three subsets, of which $\mathrm{CD} \mathrm{c}^{+}\left(\mathrm{BDCA}^{-} \mathrm{1}^{+}\right) \mathrm{mDCs}$ are the most abundant population [10-12]. Since $\mathrm{CD} 1 \mathrm{c}$, apart from $\mathrm{mDCs}$, is only expressed by a subset of B cells, this marker can be used to identify and isolate this unique subset of human mDCs $[13,14]$. CD1c is a major histocompatibility complex class I-like cell surface glycoprotein that presents lipid and glycolipid self-antigens and nonself-antigens, so $\mathrm{CD} 1 \mathrm{c}^{+} \mathrm{mDCs}$ can activate restricted lipid antigenspecific $\mathrm{T}$ cells [15]. However, these $\mathrm{mDCs}$ also have a strong capacity to induce a major histocompatibility complex-dependent antigen-driven allogeneic mixed lymphocyte reaction [11]. $\mathrm{CD} 1 \mathrm{c}^{+} \mathrm{mDCs}$ in the circulation have been suggested to represent immature DCs that express CD86 and respond to microbial products rather than to inflammatory stimuli (such as tumour necrosis factor alpha) [12]. Recently, $\mathrm{CD} 1 \mathrm{c}^{+} \mathrm{mDCs}$ were described to have an immunoregulatory function in response to certain microbial triggers $[16,17]$.

Despite the fact that $\mathrm{mDCs}$ have been extensively studied in immune disorders in mice and man and that they have been suggested to play an important role in the pathogenesis of RA [18], functional data on naturally occurring $\mathrm{mDCs}$ in $\mathrm{RA}$, including those expressing $\mathrm{CD} 1 \mathrm{c}$, are scarce. Previous studies on $\mathrm{mDC}$ in $\mathrm{RA}$ were based on CD33/CD14 expression, describing a larger $\mathrm{mDC}$ population than the recently defined $\mathrm{CD} 1 \mathrm{c}^{+} \mathrm{mDCs}$ [19], since CD33 is not only expressed on $\mathrm{CD}^{+} \mathrm{c}^{+} \mathrm{mDCs}$ but also on $\mathrm{CD} 16^{+}$and $\mathrm{BDCA}-3^{+} \mathrm{DC}$ subpopulations [11]. Only a small percentage of $\mathrm{CD} 1 \mathrm{c}^{+} \mathrm{mDCs}$ express $\mathrm{CD} 14$ and the function of these double-positive $\mathrm{mDCs}$ is still unknown [20]. In RA, mDCs are increased in the joints as compared with the circulation and express costimulatory molecules $[21,22]$. However, a detailed analysis of the capacity of ex vivo cultured $\mathrm{CD}_{1 \mathrm{c}}{ }^{+} \mathrm{mDCs}$ from RA patients to produce inflammatory mediators and activate $\mathrm{T}$ cells has not been performed.

In the present study, the function of $\mathrm{CD} 1 \mathrm{c}^{+} \mathrm{mDCs}$ (also referred to as $\mathrm{mDCs}$ ) from peripheral blood (PB) and synovial fluid (SF) of RA patients was examined. The capacity of mDCs to secrete $\mathrm{T}$ cell-differentiating cytokines (including IL-12, IL-33, IL-23), chemokines (including CCL17/thymus and activation-regulated chemokine (TARC), CXCL9/monokine induced by interferon-gamma (MIG), CXCL10/interferon-gamma inducible protein-10 (IP-10)) and proinflammatory cytokines (including IL-1 $\beta$, IL-6) was studied in combination with their capacity to induce autologous $\mathrm{T}$ cell proliferation and cytokine production (IFNy, IL-17 and IL-4).

\section{Methods \\ Patients}

The patients included in this study all met the American College of Rheumatology criteria for RA [23]. Demographic and clinical data of these patients are presented in Table 1. SF and PB samples were collected from the patients. Ethical approval for this study was given by the medical ethical committee of the University Medical Center Utrecht for the collection of patient samples in compliance with the Helsinki Declaration. All patients gave their informed consent.

\section{Flow cytometry}

The number and characteristics of $\mathrm{CD}_{1} \mathrm{c}^{+} \mathrm{mDCs}$ present in mononuclear cell (MNC) fractions of paired PB and SF samples of RA patients were analysed by fluorescence-activated cell sorting (FACS) analysis using a FACS CANTO II flow cytometer (BD Biosciences, San Jose, CA, USA). Cells were stained for CD1c-PE (Biolegend, San Diego, CA, USA), CD19-PERCP-Cy5.5 (BD Biosciences) and CD14 -APC (BD Pharmingen, San Diego, CA, USA) and were identified as CD19-negative and CD1c-positive. Cell surface marker expression on $\mathrm{CD} \mathrm{c}^{+} \mathrm{mDCs}$ was studied with the following reagents: IgG isotype FITC/PE (Immunotech, Marseille, France), HLA-DR/DP/DQ-FITC (BD Pharmingen), CD80PE, CD86-PE, CD40-PE and CD19-PERCP-Cy5.5 (all BD Biosciences), and CD1c-Pacific Blue (Biolegend). All data were analysed using FlowJo software (Tree Star, Ashland, OR, USA). To compare mean fluorescence intensity (MFI) values of human leukocyte antigen (HLA) class II, CD80, CD86 and CD40 expression on mDCs from PB and SF, the intensity of autofluorescence assessed using isotype controls 
Table 1 Demographic and clinical characteristics of rheumatoid arthritis patients

\begin{tabular}{lccc}
\hline & PB & SF & Paired PB + SF \\
\hline Age (years) & $51 \pm 11$ & $44 \pm 6$ & $48 \pm 19$ \\
$\begin{array}{l}\text { Gender } \\
\text { (male/female) }\end{array}$ & $4 / 7$ & $0 / 5$ & $8 / 10$ \\
$\begin{array}{l}\text { Disease duration } \\
\text { (years) }\end{array}$ & $15 \pm 10$ & $16 \pm 2$ & $13 \pm 8$ \\
$\begin{array}{l}\text { Rheumatoid factor } \\
\text { (positive/negative) }\end{array}$ & $6 / 5$ & $2 / 3$ & $6 / 9^{\mathrm{a}}$ \\
$\begin{array}{l}\text { Erythrocyte sedimentation } \\
\text { rate (mm/hour) }\end{array}$ & $16 \pm 19$ & $26 \pm 22$ & $34 \pm 22$ \\
$\begin{array}{l}\text { C-reactive protein } \\
\text { (mg/l) }\end{array}$ & $3 \pm 2^{\mathrm{b}}$ & $14 \pm 7$ & $39 \pm 61^{\mathrm{b}}$ \\
$\begin{array}{l}\text { Treatment } \\
\text { (NSAID/corticosteroids/ } \\
\text { DMARD/biological) }\end{array}$ & $0 / 0 / 9 / 2$ & $0 / 0 / 2 / 3$ & $1 / 4 / 5 / 5^{\mathrm{a}}$ \\
\hline
\end{tabular}

Data presented as mean \pm standard deviation or number. DMARD, diseasemodifying anti-rheumatic drugs; NSAID, nonsteroidal anti-inflammatory drugs; PB, peripheral blood; SF, synovial fluid. ${ }^{\mathrm{a}}$ Three and ${ }^{\mathrm{b}}$ eight missing values, respectively.

from $\mathrm{PB} \mathrm{mDCs}$ and $\mathrm{SF} \mathrm{mDCs}$ was subtracted from the MFI of the stainings to reveal true expression differences.

\section{Cell isolation}

MNCs from lithium-heparinised PB and SF were isolated by density centrifugation using Ficoll-Paque Plus (GE Healthcare, Uppsala, Sweden). Prior to MNC isolation, PB or SF was diluted 1:1 with RPMI 1640 medium (Gibco, Life Technologies, New York, USA) containing penicillin $(100 \mathrm{U} / \mathrm{ml})$, streptomycin $(100 \mu \mathrm{g} / \mathrm{ml})$, and $\mathrm{L}-$ glutamine $(2 \mathrm{mM})$ (all PAA Laboratories, Pasching, Austria). $\mathrm{CD}_{1} \mathrm{c}^{+} \mathrm{mDCs}$ from $\mathrm{PB}$ and $\mathrm{SF}$ and $\mathrm{CD} 4^{+} \mathrm{T}$ cells from $\mathrm{PB}$ were isolated from $\mathrm{MNC}$ fractions by magnetic-activated cell sorting using $\mathrm{CD} 1 \mathrm{c}^{+}\left(\mathrm{BDCA}-1^{+}\right)$ $\mathrm{DC}$ and $\mathrm{CD}^{+}{ }^{+} \mathrm{T}$ cell isolation kits (Miltenyi Biotec, Bergisch Gladbach, Germany), respectively, according to the manufacturer's instructions.

\section{Cell cultures}

Cells were cultured in RPMI glutamax (Gibco) supplemented with penicillin $(100 \mathrm{U} / \mathrm{ml})$, streptomycin $(100 \mu \mathrm{g} / \mathrm{ml})$, and $10 \%$ human $\mathrm{AB}$ serum (v/v; GemCell, West Sacramento, $\mathrm{CA}$, USA). Isolated $\mathrm{CD} 4^{+} \mathrm{T}$ cells were seeded in roundbottomed 96-well plates (NUNC, Roskilde, Denmark) at a concentration of $0.5 \times 10^{6}$ cells $/ \mathrm{ml}$ and stored at $37^{\circ} \mathrm{C}$ before co-culturing with $\mathrm{mDCs}$. The viable $\mathrm{mDCs}$ were counted and equal amounts of live cells were either cultured alone or cocultured with $\mathrm{CD} 4^{+} \mathrm{T}$ cells. To measure cytokine production, isolated $\mathrm{mDCs}$ from $\mathrm{PB}$ and $\mathrm{SF}$ of RA patients were cultured at a concentration of $0.5 \times 10^{6}$ cells $/ \mathrm{ml}$ for 20 hours at $37^{\circ} \mathrm{C}$. Supernatants were harvested and tested for multiple cytokines with multiplex immunoassay. To determine the effect of PB-derived and SF- derived mDCs $\left(\leq 10,000\right.$ cells/well) on autologous $\mathrm{CD}^{+}{ }^{+} \mathrm{T}$ cells $(50,000$ cells/well), mDCs derived from PB or SF were added to autologous peripheral $\mathrm{CD}_{4}^{+} \mathrm{T}$ cells in triplicate at increasing DC:T cell ratios in the absence of additional stimuli. To determine the effect of CD80/ 86-dependent costimulation in $\mathrm{SF} \mathrm{mDC} / \mathrm{T}$ cell cocultures, cells were cultured in the presence of CTLA4Ig $(10 \mu \mathrm{g} / \mathrm{ml}$; Bristol-Myers Squibb, New York, NY, USA). To study whether the observed differences between $\mathrm{PB} \mathrm{mDCs}$ and $\mathrm{SF} \mathrm{mDCs}$ were related to $\mathrm{mDC}$ maturation, as a control we activated $\mathrm{mDCs}$ from $\mathrm{PB}$ with thymic stromal lymphopoeitin (TSLP, $20 \mathrm{ng} / \mathrm{ml}$ for 20 hours preceding coculture; R\&D Systems, Minneapolis, MN, USA). Cells were cocultured in round-bottomed 96well plates for 6 days and subsequently proliferation and cytokine production were measured. Proliferation was measured by ${ }^{3} \mathrm{H}$-thymidine incorporation assay at the end of the culture period. ${ }^{3} \mathrm{H}$-thymidine $(1 \mu \mathrm{Ci} /$ well; PerkinElmer, Waltham, MA, USA) was added during the last 18 hours of the culture period. T cell cytokine production was measured in supernatants of cocultured cells upon short-term restimulation with $500 \mathrm{ng} / \mathrm{ml}$ ionomycin and $50 \mathrm{ng} / \mathrm{ml}$ phorbol myristate acetate (both Sigma-Aldrich, St Louis, MO, USA) during the last 24 hours of the culture period.

\section{Cytokine assessment}

Cytokines and chemokines in supernatants of cultured mDCs derived from PB and SF were assessed by a multiplex immunoassay as described elsewhere [24]. The cytokines measured and their expression levels are presented in Table 2 . $\mathrm{T}$ cell cytokines produced by $\mathrm{CD} 4^{+} \mathrm{T}$ cells cocultured with $\mathrm{CD} 1 \mathrm{c}^{+} \mathrm{mDCs}$ were analysed upon restimulation with ionomycin/phorbol myristate acetate. IFNy, IL-4 (Invitrogen, Life Technologies, New York, USA) and IL-17 (R\&D Systems) were measured by enzyme-linked immunosorbent assay according to the manufacturer's instructions.

\section{Statistical analysis}

Paired-sample evaluation was performed using the nonparametric Wilcoxon signed-rank test. Unpaired data analysis was performed using the nonparametric Mann-Whitney $U$ test. Data analysis was performed using SPSS software (IBM, Armonk, NY, USA). Data were considered statistically significant at $P<0.05$.

\section{Results}

$\mathrm{CD}_{1 c^{+}} \mathrm{mDCs}$ have an increased frequency and activated phenotype in RA synovial fluid

$\mathrm{mDCs}$ were characterised by the expression of $\mathrm{CD} 1 \mathrm{c}$ and the absence of CD19 in MNC fractions of paired PB and SF samples $(n=10)$ of RA patients (representative dot plot; Figure 1A). The number of mDCs, determined 
Table 2 Cytokines assessed in supernatants of cultured CD1c ${ }^{+}$myeloid dendritic cells derived from PB and SF of rheumatoid arthritis patients

\begin{tabular}{|c|c|c|}
\hline & $\mathrm{PB}(\mathrm{pg} / \mathrm{ml})$ & $\mathrm{SF}(\mathrm{pg} / \mathrm{ml})$ \\
\hline \multicolumn{3}{|l|}{ Proinflammatory cytokines } \\
\hline $\mathrm{IL}-1 \mathrm{a}$ & 409 (150) & $344(343)$ \\
\hline$I L-1 \beta$ & $258(65.5)$ & $298(280)$ \\
\hline IL-1RA & $2,561(1,034)$ & $2,769(3,531)$ \\
\hline IL-6 & $41.0(13.3)$ & $29.6(22.6)$ \\
\hline IL-6R & $324(100)$ & $343(199)$ \\
\hline IL-18 & $149(47.9)$ & $180(165)$ \\
\hline Tumour necrosis factor alpha & $99.1(95.5)$ & $170(165)$ \\
\hline Interferon alpha & $153(69.5)$ & $157(168)$ \\
\hline Thymic stromal lymphopoeitin & $<\mathrm{LDL}$ & $<\mathrm{LDL}$ \\
\hline \multicolumn{3}{|l|}{$\mathrm{T}$ cell-differentiating and $\mathrm{T}$ cell-activating cytokines } \\
\hline IL-12p70 & $17.6(11.1)$ & $18.9(18.5)$ \\
\hline IL-23 & $444(354)$ & $420(393)$ \\
\hline IL-33 & $260(101)$ & $336(391)$ \\
\hline IL-13 & $857(387)$ & $1,054(1,426)$ \\
\hline $\mathrm{IL}-10$ & $112(49.9)$ & $126(63.1)$ \\
\hline Macrophage migration inhibitory factor & $1,872(704)$ & $2,948(1,960)$ \\
\hline IL-7 & $25.8(6.9)$ & $29.2(29.7)$ \\
\hline IL-9 & $3,087(1,195)$ & $3,280(3,758)$ \\
\hline IL-15 & $21.7(8.7)$ & $29.4(27.3)$ \\
\hline IL-21 & $5,114(1,834)$ & $6,343(4,710)$ \\
\hline IL-22 & $19.2(6.1)$ & $29.0(27.3)$ \\
\hline IL-25 & $1,140(526)$ & $1,239(1,310)$ \\
\hline \multicolumn{3}{|l|}{ Chemokines } \\
\hline IL-16 & $239(101)$ & $633(581)^{\dagger}$ \\
\hline CCL2/MCP1 & $29.7(18.5)$ & $24.6(25.5)$ \\
\hline CCL3/MIP1a & $1,268(1,847)$ & $2,776(3,954)$ \\
\hline CCL5/RANTES & $<\mathrm{LDL}$ & $<\mathrm{LDL}$ \\
\hline CCL17/TARC & $1.2(0.5)$ & $26.4(23.6)^{* *}$ \\
\hline CCL19/MIP3 $\beta$ & $28.4(11.5)$ & $57.5(51.5)$ \\
\hline CCL22/MDC & $4,397(1,627)$ & $2,456(1,023)^{*}$ \\
\hline CXCL9/MIG & $23.9(16.1)$ & $90.4(67.9)^{* *}$ \\
\hline CXCL10/IP-10 & $54.0(70.3)$ & $247(310)^{*}$ \\
\hline \multicolumn{3}{|l|}{ Growth factors/others } \\
\hline Oncostatin M & $28.0(21.7)$ & $23.5(17.8)$ \\
\hline Fibroblast growth factor basic & $4,046(1,647)$ & $4,777(5,559)$ \\
\hline Nerve growth factor & $63.0(23.2)$ & $76.7(90.2)$ \\
\hline Hepatocyte growth factor & $118(46.8)$ & $151(143)$ \\
\hline Granulocyte-macrophage colony-stimulating factor & $650(283)$ & $827(859)$ \\
\hline Macrophage colony-stimulating factor & $484(188)$ & $571(730)$ \\
\hline Vascular endothelial growth factor & $191(110)$ & $202(125)$ \\
\hline $\mathrm{IL}-11$ & $49.6(20.1)$ & $53.6(63.9)$ \\
\hline Soluble intracellular adhesion molecule-1 & $34,067(139,11)$ & $37,260(46,225$ \\
\hline Osteopontin & $11,192(4,471)$ & $15,528(10,471)$ \\
\hline
\end{tabular}


Table 2 Cytokines assessed in supernatants of cultured CD1c ${ }^{+}$myeloid dendritic cells derived from PB and SF of rheumatoid arthritis patients (Continued)

\begin{tabular}{lcc}
\hline Matrix metalloproteinase-8 & $2,237(1,594)$ & $2,742(4,634)$ \\
Tissue inhibitor of metalloproteinases-1 & $2,689(1,126)$ & $2,455(2,169)$ \\
Cathepsin B & $4,204(1,554)$ & $6,283(4,948)$ \\
Cathepsin L & $215(101)$ & $594(731)$ \\
Cathepsin S & $133(55.3)$ & $159(130)$
\end{tabular}

Data presented as mean (standard deviation). IP-10, interferon-gamma inducible protein-10; LDL, lower detection limit; MCP-1, monocyte chemotactic protein-1; MDC, macrophage-derived chemokine; MIG, monokine induced by interferon-gamma; MIP, macrophage inflammatory protein; PB, peripheral blood; RANTES, regulated upon activation, normally $T$ cell-expressed, and presumably secreted; SF, synovial fluid; TARC, thymus and activation-regulated chemokine; IL, interleukin. ${ }^{*} P<0.05$; ${ }^{* *} P<0.01 ;{ }^{\dagger} P=0.10$.

as a percentage of total MNCs, was significantly increased in SF versus $\mathrm{PB}$ (mean \pm standard error of the mean: $4.7 \pm$ $1.5 \%$ vs. $0.6 \pm 0.1 \%$, respectively, $P<0.01$ ) as well as the CD1c expression (MFI: $778 \pm 97$ vs. $372 \pm 18$, respectively, $P<0.01$; Figure 1B). Cell surface markers on mDCs derived from PB and SF of RA patients were also studied ( $n=3$ and $n=5$, respectively). mDCs derived from SF compared with those from PB expressed increased levels of antigen-presenting molecules HLA class II and costimulatory molecules CD80, CD86 and CD40 (representative histograms and MFI; Figure $1 C$ ). In addition to the MFI, the percentage of SF mDCs expressing all these activation markers was also significantly increased compared with $\mathrm{PB}$ mDCs (mean \pm standard error of the mean \%
A

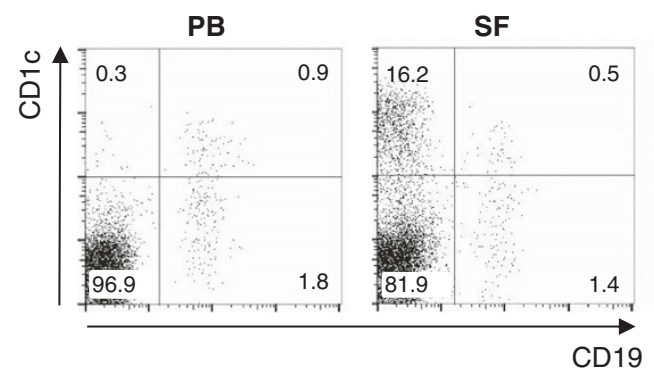

C
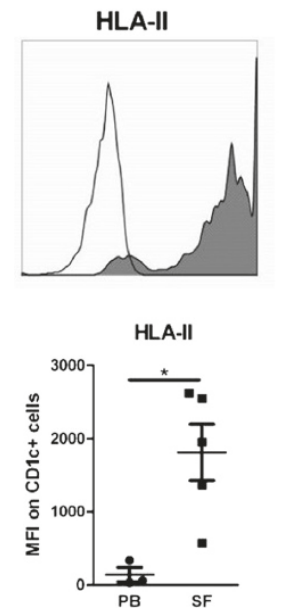

CD80
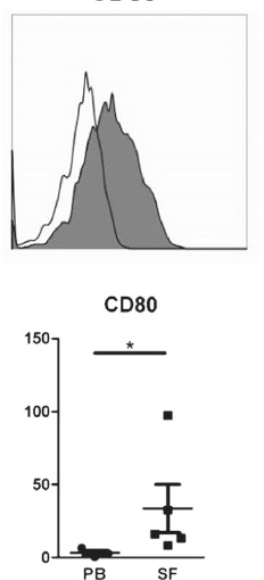

B
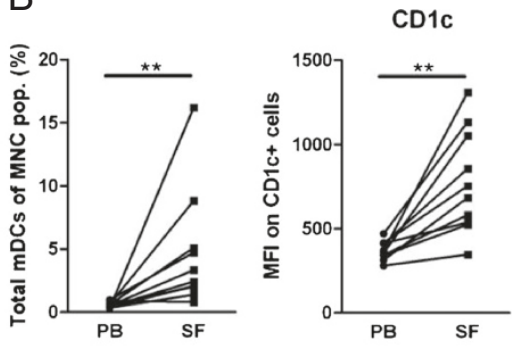

CD86
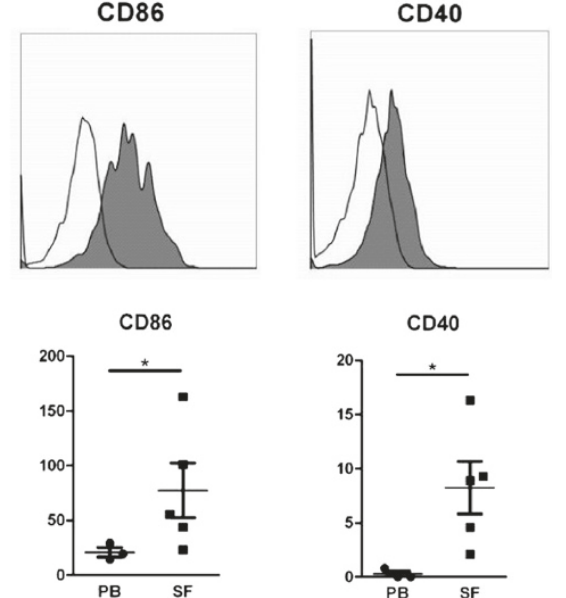

$\operatorname{CD} 40$

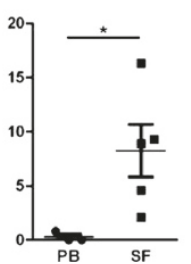

Figure $1 \mathrm{CD}^{+} \mathrm{c}^{+}$myeloid dendritic cells are abundantly present in joints of rheumatoid arthritis patients and express increased levels of antigen-presenting and costimulatory molecules. (A) Representative fluorescence-activated cell sorting (FACS) dot plot of CD1C-expressing myeloid dendritic cells (mDCs) and CD19+ cells in the peripheral blood (PB) and synovial fluid (SF) of a rheumatoid arthritis (RA) patient. (B) mDC numbers are increased in SF versus PB of RA patients $(n=10)$, and SF mDCs express higher CD1c levels. Percentages (\%) of the total mononuclear cell (MNC) population and mean fluorescent intensity (MFI) of CD1c expression are given. (C) mDCs derived from SF $(n=5)$ express enhanced levels of antigen-presenting (human leukocyte antigen class II (HLA-II)) and costimulatory molecules (CD80, CD86 and CD40) as compared with PB-derived mDCs $(n=3)$. Representative histograms of isotype control (open) and HLA-II, CD80, CD86 and CD40 (filled) expression and mean are shown (MFI corrected for isotype fluorescence). Statistically significant differences of ${ }^{*} P<0.05$ and ${ }^{* *} P<0.01$. 
positive cells in PB vs. SF, respectively: HLA class II, $39 \pm$ $10 \%$ vs. $90 \pm 3 \%, P<0.05 ; \mathrm{CD} 80,4 \pm 1 \%$ vs. $35 \pm 10 \%$, $P<0.05 ; \mathrm{CD} 86,30 \pm 7 \%$ vs. $63 \pm 10 \%, P=0.07$; CD 40 , $0.2 \pm 0 \%$ vs. $11 \pm 3 \%, P<0.05)$.

\section{Synovial fluid-derived $\mathrm{CD}_{1 \mathrm{c}^{+}} \mathrm{mDC}$ s from RA patients} secrete higher levels of specific cytokines compared with peripheral blood $\mathrm{mDCs}$

To study the functional properties of $\mathrm{CD}^{+} \mathrm{c}^{+} \mathrm{mDC}$ s these were isolated from PB MNCs and SF MNCs of RA patients $(n=6$; representative dot plot, Figure 2A). A small subset of $\mathrm{CD}_{1 \mathrm{c}}{ }^{+} \mathrm{mDCs}$ has been described to express CD14. Therefore, the percentage of CD14-expresssing cells was assessed in $\mathrm{CD} 19^{-} \mathrm{MNC}$ fractions and in isolated $\mathrm{CD}_{1} \mathrm{c}^{+}$cells. Only a small proportion of isolated $\mathrm{CD} 1 \mathrm{c}^{+}$ cells expressed CD14, to a similar extent on CD1 $\mathrm{c}^{+} \mathrm{mDCs}$ from $\mathrm{PB}$ and $\mathrm{SF}(n=6$; representative dot plots and mean of paired $\mathrm{PB}$ and SF samples, Figure $2 \mathrm{~B}$ ).

Isolated $\mathrm{CD}_{1 \mathrm{c}^{+}}$cells were cultured for 20 hours in the absence of stimuli and cytokine production was assessed (Table 2). Production of T cell-differentiating cytokines IL- 12p70, IL-33, IL-1 $\beta$, and IL-23 by mDCs from SF was not significantly different from that of $\mathrm{PB}$ mDCs (all $P>0.10$; Figure $2 \mathrm{C}$ ). The secretion of the chemoattractive mediators IP-10, MIG, and TARC by SF mDCs was significantly increased as compared with $\mathrm{PB} \mathrm{mDCs}$. Macrophagederived chemokine (MDC) production was significantly decreased by SF mDCs compared with PB mDCs (Figure 2D). The production of the T cell attractant IL-16 by SF mDCs was also elevated compared with $\mathrm{PB} \mathrm{mDCs}$, although this did not reach statistical significance $(P=0.10$; Figure $2 D)$.

Inflammatory mediators that were under the detection limit included RANTES (regulated upon activation, normally $\mathrm{T}$ cell-expressed, and presumably secreted) and TSLP. All other mediators were secreted in equal amounts by PB and SF mDCs (all $P>0.10$ ) (Table 2).

\section{Intra-articular $\mathrm{CD}_{1} \mathrm{c}^{+} \mathrm{mDC}$ spontaneously induce} proliferation and cytokine secretion of autologous $\mathrm{CD}^{+} \mathrm{T}$ cells in RA patients

Since mDCs from SF express increased levels of antigenpresenting and costimulatory molecules and produced
A

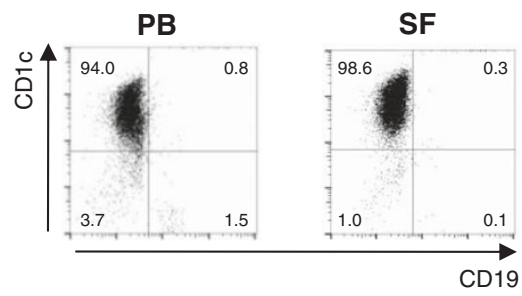

B

PB
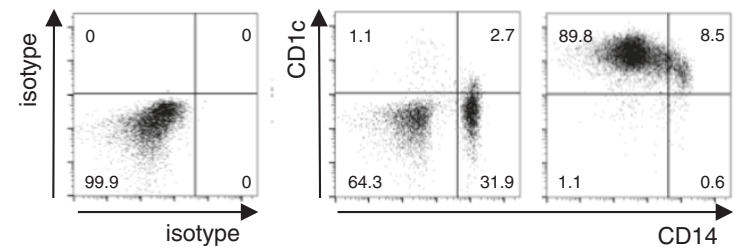

SF
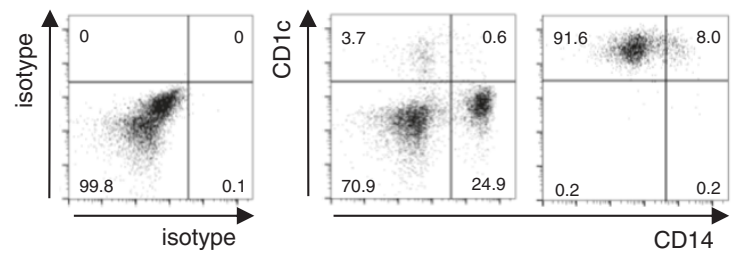
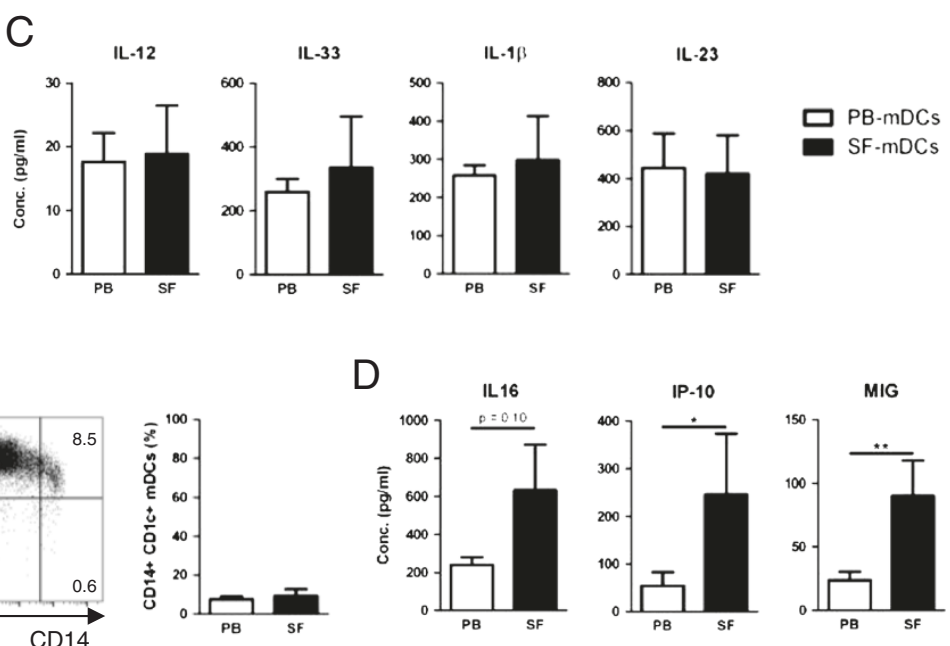

D
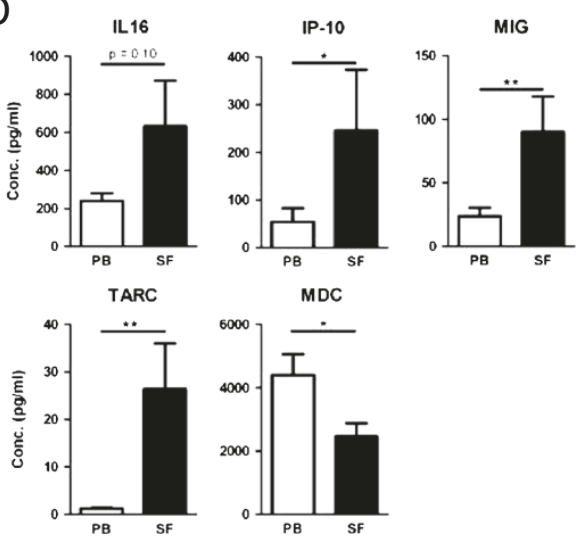

Figure $2 \mathrm{CD}^{+} \mathrm{c}^{+}$myeloid dendritic cells from synovial fluid of rheumatoid arthritis patients produce increased chemokine levels but equal amounts of T cell-differentiating cytokines compared with those from peripheral blood. (A) Representative dot plot of isolated CD1c-expressing myeloid dendritic cells (mDCs) from peripheral blood (PB) and synovial fluid (SF) of a rheumatoid arthritis (RA) patient. (B) Representative dot plots of isotype (left), CD1C and CD14 expression on CD19- mononuclear cells (middle) and on isolated mDCs (right plot) from PB and SF. A small percentage of $\mathrm{mDCs}$ from PB and SF ( $n=6$, paired samples) expresses CD14 (bar graph). (C) PB mDCs and SF mDCs ( $n=6$ ) produced comparable levels of T-helper type (Th)-1, Th17 and Th2-differentiating cytokines interleukin (IL)-12, IL-23, IL-33. (D) Production of several chemokines by SF mDCs was significantly upregulated and macrophage-derived chemokine (MDC) significantly downregulated as compared with PB mDCs. Apart from the T cell-differentiating cytokines, only inflammatory mediators that showed $P \leq 0.10$ are shown. Statistically significant differences of ${ }^{*} P<0.05$ and ${ }^{*} P<0.01$. IP-10, interferon-gamma inducible protein-10; MIG, monokine induced by interferon-gamma; TARC, thymus and activation-regulated chemokine. 
abundant amounts of $\mathrm{T}$ cell-differentiating cytokines as well as increased levels of several inflammatory mediators compared with $\mathrm{mDCs}$ from $\mathrm{PB}$, we investigated the capacity of PB-derived and SF-derived $\operatorname{mDCs}(n=11$ and $n=$ 5 , respectively) to activate autologous $\mathrm{CD} 4^{+} \mathrm{T}$ cells. $\mathrm{CD} 4^{+}$ $\mathrm{T}$ cells co-cultured with SF mDCs showed a robust increase in the induction of $\mathrm{T}$ cell proliferation compared with PB mDCs (PB mDCs vs. SF mDCs:CD4 T cells (1:5), $1,503 \pm 443$ vs. $26,935 \pm 7,543$ counts/minute, $P<0.01$, respectively; Figure $3 \mathrm{~A})$. Similar increased $\mathrm{T}$ cell activation was observed when paired $\mathrm{PB}$ and $\mathrm{SF}$ mDCs from the same donor were analysed (Figure $3 \mathrm{~B}$ ). The increase in the induction of $\mathrm{T}$ cell proliferation was also associated with a robust increase in the production of $\mathrm{T}$ cell cytokines, measured after restimulation with ionomycin/phorbol myristate acetate. The production of IFNy, IL-17 and IL- 4 was higher by $\mathrm{SF} \mathrm{mDC}$ sersus $\mathrm{PB} \mathrm{mDCs}$ (Figure $3 \mathrm{C}$ ). To test whether enhanced SF mDC-induced T cell activation was dependent on CD80/86 upregulation, CD80/86 costimulation was blocked by CTLA4-Ig. SF mDCinduced $\mathrm{T}$ cell activation was completely blocked by CTLA4-Ig (Figure 3D). To study whether the observed differences between $\mathrm{PB}$ and $\mathrm{SF}$ mDCs were related to $\mathrm{DC}$ maturation, as a control, we activated $\mathrm{mDC}$ from $\mathrm{PB}$ with
TSLP, previously shown to activate CD $11 \mathrm{c}^{+} \mathrm{DCs}$ and implicated to play a proinflammatory role in RA $[25,26]$. TSLP-stimulated $\mathrm{CD}^{+} \mathrm{c}^{+} \mathrm{mDC}$ induced robust proliferation of autologous $\mathrm{CD}^{+} \mathrm{T}$ cells (unstimulated vs. TSLPstimulated mDCs:CD4 T cells (1:5), proliferation: from $1,000 \pm 284$ to $14,206 \pm 2,426$ counts/minute, $P=0.01$, respectively; $n=8$ from $\mathrm{PB}$ of healthy controls).

\section{Discussion}

Hitherto, functional data on $\mathrm{CD} 1 \mathrm{c}^{+}\left(\mathrm{BDCA}-1^{+}\right) \mathrm{mDCs}$ from RA patients are scarce. Here we demonstrate that in RA patients naturally occurring $\mathrm{CD}_{1} \mathrm{c}^{+} \mathrm{mDCs}$ are present in higher frequency in SF and that these mDCs have an activated phenotype and secrete increased levels of a unique set of chemokines in comparison with mDCs from $\mathrm{PB}$. To our knowledge this is also the first study that reports $\mathrm{CD} 1 \mathrm{c}^{+} \mathrm{mDCs}$ from SF of RA patients to compellingly cause autologous $\mathrm{T}$ cell activation.

The majority of $\mathrm{T}$ cells present in SF of RA patients were previously shown to express the CXC chemokine receptor 3 (CXCR3), with a higher percentage of $\mathrm{T}$ cells expressing CXCR3 in SF than in $\mathrm{PB}$ of RA patients $[27,28]$. CXCR3 is mainly expressed on Th1 cells and binds to its ligands CXCL10/IP-10 and CXCL9/MIG

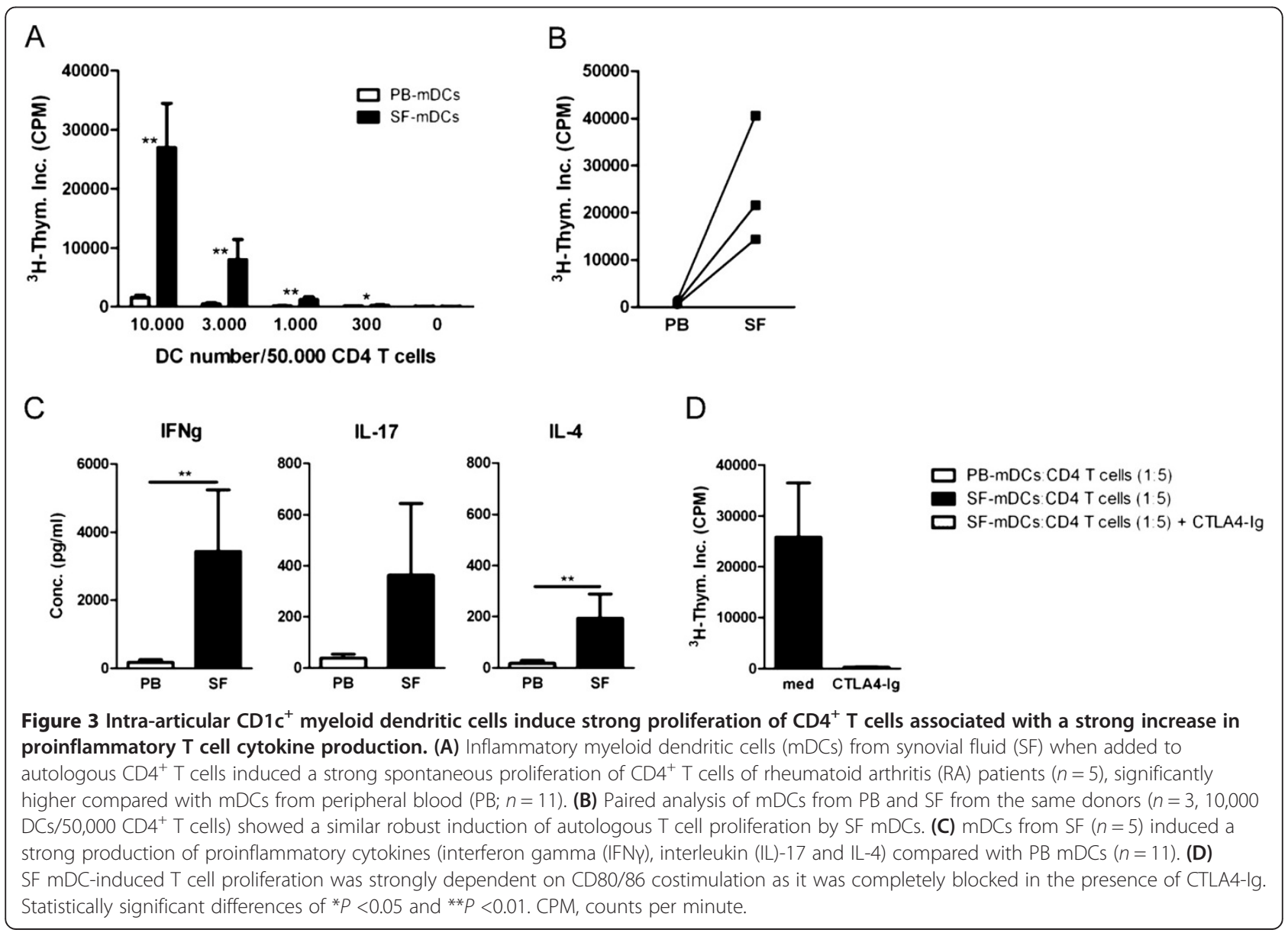


$[29,30]$. Elevated IP-10 and MIG levels are observed in SF of RA patients compared with control SF from patients with osteoarthritis or traumatic joint injury [27], and the present study shows that in vivo-activated CD1c ${ }^{+}$ mDCs from RA joints secrete high levels of IP-10 and MIG. Furthermore, these mDCs secrete higher CCL17/ TARC levels compared with mDCs derived from $\mathrm{PB}$. TARC is a selective ligand for the $\mathrm{CC}$ chemokine receptor 4 (CCR4) that is expressed by Th2 cells $[29,30]$, Th17 cells [31], and regulatory $T$ cells [32], suggesting that TARC contributes to attraction of these $\mathrm{T}$ cells into the inflamed joints. Secretion of CCL22/MDC by SF mDCs, another CCR4 ligand, was significantly lower compared with that by $\mathrm{PB}$ mDCs. To what extent this differential expression of CCR4 ligands influences the chemotaxis of Th2, Th17 and regulatory T cells remains to be demonstrated. Recently, it was demonstrated that MDC levels in SF of RA patients are elevated compared with osteoarthritis patients [33]. This may indicate that other cell types could contribute to these enhanced levels. Alternatively, the increased number of $\mathrm{CD} 1 \mathrm{c}^{+}$ mDCs ( 5-fold higher) in the joint compared with the circulation of RA patients could contribute to elevated intra-articular levels.

Apart from enhancing immune activation, DCs induced under different conditions can also induce tolerance - by increasing regulatory $\mathrm{T}$ cell activity, amongst other effects $[7,8]$. Our data demonstrate that, in line with the enhanced expression of antigen-presenting and costimulatory molecules, SF-derived CD1c ${ }^{+}$mDCs spontaneously increased proliferation and Th1, Th17 and Th2 cell cytokine production of autologous $\mathrm{CD}^{+} \mathrm{T}$ cells. Although we did not measure regulatory $\mathrm{T}$ cell function, our data demonstrate that $\mathrm{mDCs}$ from SF overrule suppression by regulatory $\mathrm{T}$ cells and indicate that in vivo-activated $\mathrm{CD} 1 \mathrm{c}^{+}$ $\mathrm{mDCs}$ from the joint have a strong capacity to induce $\mathrm{T}$ cell expansion of infiltrating $\mathrm{T}$ cells without strongly skewing the $\mathrm{T}$ cell balance. In line with this observation, $\mathrm{SF}$ and $\mathrm{PB} \mathrm{mDCs}$ secreted equal amounts of $\mathrm{T}$ celldifferentiating cytokines. Since in RA joints a predominance of Th1 and Th17 activity is observed, our data suggest that in joints of RA patients further Th1 and Th17 cell skewing is facilitated by local inflammatory mediators (for example, IL-12) produced, for example, by macrophages.

Recently, Frankenberger and colleagues showed via gene expression analysis that $\mathrm{CD} 14^{++} \mathrm{CD} 16^{-}$as well as $\mathrm{CD}_{16}{ }^{+}$monocytes are both distinct from the $\mathrm{CD} 1 \mathrm{c}^{+}$ blood DCs [34]. In the present study, CD14-expressing cells that lacked CD1c were not present or were hardly present in the isolated DC fractions ( $\sim 0.5 \%)$; however, a small percentage of the $\mathrm{CD}_{1 \mathrm{c}^{+}} \mathrm{mDCs}$ coexpressed CD14, similar to previous reports for healthy controls [20]. Our data demonstrate that activated mDCs from SF of RA patients show a robust homogenic upregulation of HLA class II, CD80, CD86, CD40 and CD1c compared with their circulating counterparts. This corresponds to the robust $\mathrm{T}$ cell stimulatory capacity of these SF mDCs and contradicts the assumption that a subpopulation of $\mathrm{CD}_{14}{ }^{+}$cells is responsible for the observed effects. In addition, the percentages of $\mathrm{CD} 14^{+} \mathrm{CD} 1 \mathrm{c}^{+}$mDCs between $\mathrm{PB}$ and SF did not differ. These latter suggestions are in line with the much lower $\mathrm{T}$ cell stimulatory capacity of total CD $14^{+}$monocytes, either isolated from SF or from PB (unpublished data). Recently, however, CD1c ${ }^{+}$DCs expressing CD14 were suggested to represent human inflammatory DCs, present in inflammatory environments such as ascites and RA joints, and potent inducers of Th17 cells [35]. Although individual data from RA SF cannot be deduced from this latter study, CD14 seems to be expressed at higher levels on inflammatory $\mathrm{CD}_{1 \mathrm{c}^{+}}$ mDCs versus blood CD1c ${ }^{+}$mDCs [35]. Differences in this latter study and the present study, showing low and comparable percentages of $\mathrm{CD} 14^{+} \mathrm{CD} 1 \mathrm{c}^{+} \mathrm{mDCs}$ between PB and SF, might be related to the site of inflammation studied (SF vs. ascites), but this remains to be established.

Although a wide range of triggers might activate $\mathrm{CD} 1 \mathrm{c}^{+}$ $\mathrm{mDCs}$, the predominant triggers that activate these cells in RA joints remain to be demonstrated [36]. Jongbloed and colleagues investigated the capacity of SF $\mathrm{mDCs}$ to respond to toll-like receptor-2 agonism. As compared with healthy $\mathrm{PB} \mathrm{mDCs}, \mathrm{mDCs}$ from the joints of RA patients produced equal amounts of tumour necrosis factor alpha and increased amounts of IL-10 in response to activation by Staphylococcus aureus peptidoglycan [22]. Based on this study of toll-like receptor triggering, $\mathrm{mDCs}$ from the joints of RA patients were suggested not to be activated and to display a semi-mature phenotype [22]. In line with these data the present study also failed to detect any robust differences between $\mathrm{PB}$ and SF $\mathrm{mDC}$ in secretion of cytokines (including IL-1, IL-6, tumour necrosis factor alpha, IFN $\alpha$ ) typically induced upon toll-like receptor-2 or other toll-like receptor triggering. However, the present data clearly reveal an activated status of SF mDCs and a powerful stimulation of $\mathrm{T}$ cells by these SF $\mathrm{mDCs}$, which suggests that stimuli other than toll-like receptor ligands contribute to the enhanced activity of these cells in vivo, associated with a unique set of secreted chemokines. Recently, increased levels of TSLP in SF of RA patients versus osteoarthritis patients were documented $[37,38]$. TSLP strongly induced TARC production by $\mathrm{mDCs}$ from $\mathrm{PB}$ and SF of RA patients [38]. Furthermore, mDCs from the peripheral blood, activated by TSLP, showed phenotypical and functional similarities with mDCs derived from the joints of RA patients, suggesting that TSLP might be an important trigger for $\mathrm{mDC}$ activation in RA joints [38]. 


\section{Conclusions}

There is clear evidence that multiple subsets of DCs exist, which display specialised functions although the tissue microenvironment and the stage of maturation can influence their phenotype and function. The present study suggests that accumulating $\mathrm{CD}^{+} \mathrm{c}^{+} \mathrm{mDCs}$ in the joints of RA patients importantly contribute to inflammation by inducing secretion of a unique set of T cell-attracting chemokines and by spontaneously activating $\mathrm{CD} 4^{+} \mathrm{T}$ cells to proliferate and secrete proinflammatory cytokines. The identification of the factors that control the capacity of mDCs to elicit Th1, Th17 and Th2 development in RA is critical to envisage new approaches to manipulate the immune system to the benefit of these patients.

\section{Abbreviations \\ DC: Dendritic cell; HLA: Human leukocyte antigen; IFNy: Interferon gamma; IL: Interleukin; IP-10: Interferon-gamma inducible protein-10; MDC: macrophage-derived chemokine; mDC: Myeloid dendritic cell; MIG: Monokine induced by interferon gamma; MFI: Mean fluorescence intensity; MNC: Mononuclear cell; PB: Peripheral blood; RA: Rheumatoid arthritis; SF: Synovial fluid; TARC: Thymus and activation-regulated chemokine; Th: T-helper type; TSLP: Thymic stromal lymphopoeitin.}

\section{Competing interests}

The authors declare that they have no competing interests.

\section{Authors' contributions}

FMM participated in the study design, acquisition of data, analysis and interpretation of data and writing of the manuscript. CEH contributed to the study design, interpretation of data and writing of the manuscript. KMGvdW-J and WdJ contributed to the acquisition of data. TRDJR and FPJGL were involved in the interpretation of data and writing of the manuscript. JAGVR contributed to the study design, analysis and interpretation of data and writing of the manuscript. All authors read and approved the final manuscript for publication.

\section{Acknowledgement}

This research was performed within the framework of the Center for Translational Molecular Medicine (www.ctmm.nl), and the Dutch Arthritis Foundation, project TRACER (grant 04I-202).

\section{Author details}

'Department of Rheumatology \& Clinical Immunology, University Medical Center Utrecht, PO Box 85500, 3508 GA Utrecht, the Netherlands. ${ }^{2}$ Center for Molecular and Clinical Immunology, Laboratory of Translational Immunology, University Medical Center Utrecht, PO Box 85500, 3508 GA Utrecht, the Netherlands.

Received: 13 December 2012 Accepted: 1 October 2013 Published: 20 October 2013

\section{References}

1. Feldmann M, Brennan FM, Maini RN: Rheumatoid arthritis. Cell 1996, 85:307-310

2. Morita Y, Yamamura M, Kawashima M, Harada S, Tsuji K, Shibuya K, Maruyama K, Makino H: Flow cytometric single-cell analysis of cytokine production by CD4+ T cells in synovial tissue and peripheral blood from patients with rheumatoid arthritis. Arthritis Rheum 1998, 41:1669-1676.

3. Chabaud M, Durand JM, Buchs N, Fossiez F, Page G, Frappart L, Miossec P: Human interleukin-17: a T cell-derived proinflammatory cytokine produced by the rheumatoid synovium. Arthritis Rheum 1999, 42:963-970.

4. Cornelissen F, van Hamburg JP, Lubberts E: The IL-12/IL-23 axis and its role in Th17 cell development, pathology and plasticity in arthritis. Curr Opin Investig Drugs 2009, 10:452-462.

5. van Roon JA, van Roy JL, Duits A, Lafeber FP, Bijlsma JW: Proinflammatory cytokine production and cartilage damage due to rheumatoid synovial $\mathrm{T}$ helper-1 activation is inhibited by interleukin-4. Ann Rheum Dis 1995, 54:836-840.

6. Banchereau J, Steinman RM: Dendritic cells and the control of immunity. Nature 1998, 392:245-252.

7. Coquerelle $C$, Moser M: DC subsets in positive and negative regulation of immunity. Immunol Rev 2010, 234:317-334.

8. Torres-Aguilar H, Blank M, Jara $\sqcup$, Shoenfeld $Y$ : Tolerogenic dendritic cells in autoimmune diseases: crucial players in induction and prevention of autoimmunity. Autoimmun Rev 2010, 10:8-17.

9. Steinman RM, Inaba K: Myeloid dendritic cells. J Leukoc Biol 1999, 66:205-208.

10. Dzionek A, Fuchs A, Schmidt P, Cremer S, Zysk M, Miltenyi S, Buck DW, Schmitz J: BDCA-2, BDCA-3, and BDCA-4: three markers for distinct subsets of dendritic cells in human peripheral blood. J Immunol 2000, 165:6037-6046.

11. MacDonald KP, Munster DJ, Clark GJ, Dzionek A, Schmitz J, Hart DN: Characterization of human blood dendritic cell subsets. Blood 2002, 100:4512-4520.

12. Piccioli D, Tavarini S, Borgogni E, Steri V, Nuti S, Sammicheli C, Bardelli M, Montagna $D$, Locatelli $F$, Wack A: Functional specialization of human circulating CD16 and CD1c myeloid dendritic-cell subsets. Blood 2007 109:5371-5379.

13. Small TN, Knowles RW, Keever C, Kernan NA, Collins N, O'Reilly RJ, Dupont B, Flomenberg N: M241 (CD1) expression on B lymphocytes. J Immunol 1987, 138:2864-2868.

14. Delia D, Cattoretti G, Polli N, Fontanella E, Aiello A, Giardini R, Rilke F, Della Porta G: CD1c but neither CD1a nor CD1b molecules are expressed on normal, activated, and malignant human B cells: identification of a new B-cell subset. Blood 1988, 72:241-247.

15. Beckman EM, Melian A, Behar SM, Sieling PA, Chatterjee D, Furlong ST, Matsumoto R, Rosat JP, Modlin RL, Porcelli SA: CD1C restricts responses of mycobacteria-specific T cells. Evidence for antigen presentation by a second member of the human CD1 family. J Immunol 1996, 157:2795-2803.

16. Kassianos AJ, Hardy MY, Ju X, Vijayan D, Ding Y, Vulink AJ, McDonald KJ, Jongbloed SL, Wadley RB, Wells C, et al: Human CD1c (BDCA-1) + myeloid dendritic cells secrete IL-10 and display an immuno-regulatory phenotype and function in response to Escherichia coli. Eur J Immunol 2012, 42:1512-1522.

17. Qian C, Cao X: Naturally occurring CD1C + human regulatory dendritic cells: immunoregulators that are expanded in response to $\mathrm{E}$. coli infection. Eur J Immunol 2012, 42:1388-1392.

18. Thomas R, MacDonald KP, Pettit AR, Cavanagh LL, Padmanabha J, Zehntner S: Dendritic cells and the pathogenesis of rheumatoid arthritis. J Leukoc Biol 1999, 66:286-292.

19. Thomas R, Davis LS, Lipsky PE: Rheumatoid synovium is enriched in mature antigen-presenting dendritic cells. J Immunol 1994, 152:2613-2623.

20. Ziegler-Heitbrock L, Ancuta P, Crowe S, Dalod M, Grau V, Hart DN, Leenen PJ, Liu YJ, MacPherson G, Randolph GJ, Scherberich J, Schmitz J, Shortman K, Sozzani S, Strobl H, Zembala M, Austyn JM, Lutz MB: Nomenclature of monocytes and dendritic cells in blood. Blood 2010, 116:e74-e80.

21. Smolewska E, Stanczyk J, Brozik H, Biernacka-Zielinska M, Cebula B, Robak T, Smolewski P: Distribution and clinical significance of blood dendritic cells in children with juvenile idiopathic arthritis. Ann Rheum Dis 2008, 67:762-768.

22. Jongbloed SL, Lebre MC, Fraser AR, Gracie JA, Sturrock RD, Tak PP, Mclnnes IB: Enumeration and phenotypical analysis of distinct dendritic cell subsets in psoriatic arthritis and rheumatoid arthritis. Arthritis Res Ther 2006, 8:R15.

23. Arnett FC, Edworthy SM, Bloch DA, McShane DJ, Fries JF, Cooper NS, Healey LA Kaplan SR, Liang MH, Luthra HS, et al: The American rheumatism association 1987 revised criteria for the classification of rheumatoid arthritis. Arthritis Rheum 1988, 31:315-324.

24. de Jager W, te Velthuis H, Prakken BJ, Kuis W, Rijkers GT: Simultaneous detection of 15 human cytokines in a single sample of stimulated peripheral blood mononuclear cells. Clin Diagn Lab Immunol 2003, 10:133-139.

25. Reche PA, Soumelis V, Gorman DM, Clifford T, Liu M, Travis M, Zurawski SM, Johnston J, Liu YJ, Spits H, de Waal Malefyt R, Kastelein RA, Bazan JF: Human thymic stromal lymphopoietin preferentially stimulates myeloid cells. J Immunol 2001, 167:336-343.

26. Hartgring SA, Willis CR, Dean CE Jr, Broere F, van Eden W, Bijlsma JW, Lafeber FP, van Roon JA: Critical proinflammatory role of thymic stromal lymphopoietin and its receptor in experimental autoimmune arthritis. Arthritis Rheum 2011, 63:1878-1887. 
27. Patel DD, Zachariah JP, Whichard LP: CXCR3 and CCR5 ligands in rheumatoid arthritis synovium. Clin Immunol 2001, 98:39-45.

28. Qin S, Rottman JB, Myers P, Kassam N, Weinblatt M, Loetscher M, Koch AE, Moser B, Mackay CR: The chemokine receptors CXCR3 and CCR5 mark subsets of T cells associated with certain inflammatory reactions. J Clin Invest 1998, 101:746-754

29. Bonecchi R, Bianchi G, Bordignon PP, D’Ambrosio D, Lang R, Borsatti A, Sozzani S, Allavena P, Gray PA, Mantovani A, Sinigaglia F: Differential expression of chemokine receptors and chemotactic responsiveness of type 1 T helper cells (Th1s) and Th2s. J Exp Med 1998, 187:129-134.

30. Sallusto F, Lenig D, Mackay CR, Lanzavecchia A: Flexible programs of chemokine receptor expression on human polarized T helper 1 and 2 lymphocytes. J Exp Med 1998, 187:875-883.

31. Leipe J, Grunke M, Dechant C, Reindl C, Kerzendorf U, Schulze-Koops H, Skapenko A: Role of Th17 cells in human autoimmune arthritis. Arthritis Rheum 2010, 62:2876-2885.

32. Baatar D, Olkhanud P, Sumitomo K, Taub D, Gress R, Biragyn A: Human peripheral blood T regulatory cells (Tregs), functionally primed CCR4+ Tregs and unprimed CCR4- Tregs, regulate effector T cells using FasL. J Immunol 2007, 178:4891-4900.

33. Flytlie HA, Hvid M, Lindgreen $E$, Kofod-Olsen $E$, Petersen $E L$, Jorgensen $A$ Deleuran M, Vestergaard C, Deleuran B: Expression of MDC/CCL22 and its receptor CCR4 in rheumatoid arthritis, psoriatic arthritis and osteoarthritis. Cytokine 2010, 49:24-29.

34. Frankenberger M, Hofer TP, Marei A, Dayyani F, Schewe S, Strasser C, Aldraihim A, Stanzel F, Lang R, Hoffmann R, et al: Transcript profiling of CD16-positive monocytes reveals a unique molecular fingerprint. Eur J Immunol 2012, 42:957-974.

35. Segura E, Touzot M, Bohineust A, Cappuccio A, Chiocchia G, Hosmalin A, Dalod M, Soumelis V, Amigorena S: Human inflammatory dendritic cells induce Th17 cell differentiation. Immunity 2013, 38:336-348.

36. Leslie DS, Vincent MS, Spada FM, Das H, Sugita M, Morita CT, Brenner MB: CD1-mediated gamma/delta T cell maturation of dendritic cells. J Exp Med 2002, 196:1575-1584.

37. Koyama K, Ozawa T, Hatsushika K, Ando T, Takano S, Wako M, Suenaga F, Ohnuma Y, Ohba T, Katoh R, Sugiyama H, Hamada Y, Ogawa H, Okumura K, Nakao A: A possible role for TSLP in inflammatory arthritis. Biochem Biophys Res Commun 2007, 357:99-104.

38. Moret FM, Hack CE, van der Wurff-Jacobs KMG, Lafeber FPJG, van Roon JAG TSLP: a novel potent proinflammatory mediator that activates myeloid dendritic cells to stimulate Th1 and Th17 activity in rheumatoid arthritis [abstract]. Ann Rheum Dis 2011, 70:A43-A44.

\section{doi:10.1186/ar4338}

Cite this article as: Moret et al:: Intra-articular CD1c-expressing myeloid dendritic cells from rheumatoid arthritis patients express a unique set of T cell-attracting chemokines and spontaneously induce Th1, Th17 and Th2 cell activity. Arthritis Research \& Therapy 2013 15:R155.

\section{Submit your next manuscript to BioMed Central and take full advantage of:}

- Convenient online submission

- Thorough peer review

- No space constraints or color figure charges

- Immediate publication on acceptance

- Inclusion in PubMed, CAS, Scopus and Google Scholar

- Research which is freely available for redistribution 